\title{
V. ACKNOWLEDGEMENTS
}

The writer wishes to acknowledge his indebtedness to the following:To the Directors and Staffs of the following Museums, for permission to examine and photograph the Chatham Island skulls in their care. The Museum of the Anatomy Department of the Medical School of the University of Otago; the Canterbury Museum, Christchurch; the Dominion Museum, Wellington; the Auckland War Memorial Museum; the Otago University Museum, Dunedin; the Alexander Museum, Wanganui, and the Museum of the Auckland Branch of the N.Z. Dental Association.

To the Trustees of the Australian Museum, Sydney, N.S.W., for the loan of a Chimpanzee skull. To the Surveyor-General of New Zealand and Mr. M. Crompton Smith for lending a pantograph and a planimeter, and for providing facilities for their use.

To Dr. H. D. Skinner of the Dunedin Museum for advice and for permission to borrow from his work on the Morioris.

To Professor Dodds for the use of equipment and material at the Otago University Dental School, and to Mr. H. S. Wilkinson for making some of the radiographs.

To Professor Kirk of Wellington for lending a Moriori skull.

To Professor Thomson of Oxford for the gift of photographs of Moriori skulls, and to Mr. W. Chesterman for the skill and care with which he has prepared them.

A large part of the work was done in the Anatomy Department of the University of Otago, and I am greatly indebted to Professor W. P. Gowland for facilities and equipment and materials, and for his encouragement and advice. I also wish to thank Mr. G. Howard, technician in the department, for much of the photographic work.

While the revised paper was still in England, Miss M. L. Tildesley visited New Zealand for the 1937 A.N.Z.A.A.S. Congress. She read my original paper and sent me an extensive criticism. I then discarded more of the original, undertook further practical work and again re-arranged and re-wrote the whole paper. I gratefully acknowledge that the better handling of the data owes much to her criticism and encouragement. 